This is a self-archived version of an original article. This version may differ from the original in pagination and typographic details.

Author(s): Pitkänen, Olli Petteri

Title: Schelling, esotericism and the meaning of life

Year: 2019

Version: Published version

Copyright: (c) 2019 Institute for Research in Social Communication, Slovak Academy of Scienc

Rights: In Copyright

Rights url: http://rightsstatements.org/page/InC/1.0/?language=en

Please cite the original version:

Pitkänen, O. P. (2019). Schelling, esotericism and the meaning of life. Human Affairs, 29(4), 497504. https://doi.org/10.1515/humaff-2019-0045 


\title{
SCHELLING, ESOTERICISM AND THE MEANING OF LIFE
}

\author{
OLLI PETTERI PITKÄNEN
}

\begin{abstract}
F.W.J. Schelling argues in his middle period work Philosophical Inquiries into the Nature of Human Freedom that will should be understood as the most fundamental constitutive element of reality. Though it is often downplayed in recent scholarship, Schelling derived his most central ideas for this work more or less directly from the theosophy of Jacob Boehme. I will argue that far from peripheral and antiquated curiosity, Schelling's esoteric influences constitute the very foundation of his middle period thought. Schelling's affinity to esotericism enabled him to develop a form of pantheism, which is not tied to the familiar problematic aspects of traditional Christian and post-Christian narratives. In mainstream Christianity, the meaning of life is dependent on the almighty God's will, for which nature is inherently meaningless material. For Schelling, by contrast, nature itself is constitutively willing and meaningful. Consequently, owing to his esoteric influences, Schelling provides an account of the meaning of life which diverges from the dominant idea of Western philosophical and theological tradition that the meaning of life consists in a "true world" or "destination" beyond immanent reality.
\end{abstract}

Key words: Schelling; esotericism; cosmic meaning of life; pantheism; panentheism

\section{Introduction}

In this article I relate together three recent philosophical discussions: the revival of the interest and appraisal of F.W.J. Schelling's thought, academic interest in esotericism, and the recent philosophical discussion on the meaning of life. Two of these issues have rarely been connected, and, as far as I am aware, this is the first time that all the three themes are being linked together. My argument is that, owing to his esoteric influences, Schelling provides a unique account of the meaning of life in the cosmic sense.

In the first section, I take up the central ideas of Schelling's (1809) arguably most influential work Philosophical Inquiries into the Nature of Human Freedom. In this work, generally referred as the Freedom Essay, Schelling draws heavily from western esotericism, which makes the Freedom Essay extraordinary among the classics of philosophy. There are esoteric aspects at play already in Schelling's earlier works, but at some point before writing the Freedom Essay, Schelling went through a major change of orientation, which Sean McGrath (2012, pp. 4-5) calls "the personalist turn". At this stage of his career Schelling began to emphasize the philosophical relevance of human personality, and he also adopted a conception of a personal God, though in a very peculiar sense. There are several possible

DE GRUYTER 
explanations for Schelling's change of orientation, but at least one important factor is that during this period Schelling was in close contact with Franz Baader, an enthusiast of Jacob Boehme's theosophy. Via Baader, Schelling took quite direct influences from Boehme, who in his turn was heavily influenced by alchemy and Lurianic Kabbalah.

In the second section, I will introduce the three most prominent definitions of esotericism. Then, using these definitions, I clarify Schelling's esoteric aspects in contrast to conventional idealistic philosophy. In the third section, I take up the conception of the meaning of life. ${ }^{1}$ First I argue that the meaning of the meaning of life cannot be adequately understood by semantic and analytical approaches, but it refers to the overall sense of purposiveness of the world. Next I briefly discuss Julian Young's (2014) treatment of the subject. Young takes up Nietzsche's declaration of the death of God as a watershed after which all grand narratives of progress became implausible. Twentieth century philosophers from Sartre to Derrida have taken for granted that after Nietzsche life has no meaning, or that the question of the meaning of life is a pseudo question in the first place. Young argues, by contrast, that there still is a philosophically plausible way to argue for the meaning of life. He interprets late Heidegger's thought as a form of pantheism which enables the sense of the meaning of life without the outdated ideas of a Platonic-Christian "true world" or postChristian secular narratives of a final telos (such as presented in Marxism). I am skeptical of Young's interpretation of Heidegger, but I will argue that in the Freedom Essay Schelling presents a similar pantheistic account to that which Young attributes to Heidegger. Finally, I will argue that it is precisely Schelling's engagement with esotericism which enables him to conceive life as an inherently meaningful whole in contrast to all classical narratives of Western philosophy and theology, in which the meaning of life is dependent on a transcendent telos beyond the immanent reality.

\section{Metaphysics of the Freedom Essay}

After Schelling's death in 1854 interest in his philosophy began to wane quickly, and for over hundred years Kant and Hegel were conceived as the most important figures in the legacy of German idealism both historically and for contemporary interpretations. The first treatment of Schelling as a topical thinker instead of a mere mediator between Fichte's and Hegel's systems was Martin Heidegger's lectures on Schelling's Freedom Essay in 1936. According to Heidegger, Schelling was the first thinker who questioned the dominant model of Western metaphysics, which Heidegger called "onto-theological", though, in Heidegger's view, Schelling ultimately shied away from his own conclusions (Heidegger, 1985, p. 161). It was not until the 1980s and more so in the 90s that the "rennaissance" of Schelling's thought took place on a major scale. Since then, Schelling's ideas have been utilized for example in the philosophy of physics and biology, deep ecology, psychoanalysis, political philosophy, and

\footnotetext{
1 I sharply distinguish the conception of the meaning of life from questions concerning meaning in life. Presumably, it is possible to live a meaningful life (regardless of what a subjectively meaningful life exactly consists of, or what objective conditions it may have) while not believing that life has a meaning or not even thinking the question of the meaning of life once.
} 
feminist thought. ${ }^{2}$ However, the usual standpoint in recent Schelling-scholarship has been, that, in contrast to the classical narrative of the history of philosophy, Schelling went in many ways beyond Hegel's absolute idealism and anticipated the central philosophical turns of the twentieth century. Schelling's metaphysics has rarely been treated as viable position in itself. In this article, I will, to the contrary, take seriously that aspect of Schelling's thought, which is generally deemed as the most antiquated, that is, the esoteric elements of Schelling.

The foundational question of the Freedom Essay is the compatibility of nature understood as a lawful whole and human freedom, in particular, the possibility of evil choices and their metaphysical foundation. For Schelling, however, the compatibility of causally ordered nature and spontaneous human activity is not a sharply defined philosophical question as understood in contemporary philosophy of mind. By contrast, Schelling's treatment of the subject is simultaneously concerned with profound theological and moral psychological issues. According to Schelling, conceiving nature, as a systematic whole, merely as causal continuum is completely insufficient for accounting for human freedom in any practically adequate sense. However, in Schelling's view, such a conception of nature is an essential part of modern philosophy, and: "the true conception of freedom was lacking in all modern systems, that of Leibniz as well as that of Spinoza" (Schelling, 1809, p. 17).

According to Schelling, the requirement of thorough rationality in philosophy has led to the inability to include the rational human subject himself in the whole of nature in a balanced way. On the one hand, human subjectivity is reduced to the causal processes of nature-Schelling takes Spinoza as a paradigmatic case. Referring to him, Schelling argues that "the lifelessness of his system, the harshness of its form, the bareness of its concepts and expressions, the relentless austerity of is definitions" results from the fact that "he treats the will, too, as a thing, and then proves, very naturally, that in every case of its operation it must be determined by some other thing, which in turn is determined by another, and so forth endlessly" (Schelling, 1809, p. 22). On the other hand, Schelling (1809, pp. 8-9) takes Fichte as an example of the opposite extreme: placing the human will as an absolute starting point of a philosophical system. In Schelling's view, the only way to think of genuine human freedom and the systematic whole of nature at the same time is to conceive nature itself as willing. According to Schelling, "in the final and highest instance there is no other Being than Will" (Schelling, 1809, p. 24).

Schelling's metaphysics of the will is based on his peculiar conception of God's ground. All conceptions of God as the primal being, which grounds all other beings, necessarily give rise to the question what is the ground of God himself. According to Schelling, "all philosophies say this, but they speak of this ground as a mere concept without making it something real and actual" (Schelling, 1809, p. 32). In order to justify genuine spontaneity, productivity and especially human freedom within nature, Schelling argues that "the concept

\footnotetext{
2 It is unnecessary to sum up here the recent interpretations of Schelling, for they have been documented many times elsewhere. The first highly influential monographs in the 90s were Andrew Bowie's (2006) Schelling and Modern European Philosophy, Dale Snow's (1996) Schelling and the End of Idealism, and Slavoj Žižek's The Indivisible Remainder - On Schelling and Related Matters. For compilations of various different contemporary interpretations of Schelling, see (Norman \& Welchman, 2004) and (Wirth, 2005).
} 
of becoming is the only one adequate to the nature of things" (Schelling, 1809, p. 33). However, the ground against which the becoming of things takes place cannot be outside God, insofar as God is the ground of all things. Schelling argues that "this contradiction can only be solved by things having their basis in that within God which is not God himself, i.e. in that which is the basis of his existence" (Schelling, 1809, p. 33). Consequently, Schelling diverges radically from all forms of mainstream Western theology in attributing nature and human beings in particular the ability to act in such a way which is not fully under God's control. McGrath (2012, p. 151) adequately describes Schelling's conception of the ground as God's unconscious. Schelling himself calls the ground "the will in the depths" and "the longing which the eternal One feels to give birth to itself" (Schelling, 1809, pp. 34, 52). For Schelling, this split within God into actual existence and its ground is the foundation of personality, both in divinity and in the human being (McGrath, 2012, pp. 120-121).

Schelling's distinction between God's ground and his actual orderly existence comes quite evidently from Boehme's notions of God's "dark fire" and "light fire" respectively (McGrath, 2012, p. 125). According to Boehme, God awakens a desire in himself, but as there is yet nothing else than God, it can only be a desire for his own actualization (McGrath, 2012, p. 54). Similar to Boehme, Schelling's conception of the ground implies that blind desire is prior to God's actual will which is associated with order and goodness. It is also important to note that God's ground must not be understood in causal-temporal terms. By contrast, the ground is an integral element in the order of nature. It is "the incomprehensible basis of reality in things, the irreducible remainder which cannot be resolved into reason by the greatest exertion but always remains in the depths" (Schelling, 1809, p. 34). For Schelling, God is a constant process; nature is not the realization of an idea in the mind of an omnipotent being but God himself actualized in nature and in the human being in particular.

\section{Esotericism as the "rejected Other" of Western rationality}

Esotericism was not an extensively studied subject until the 1990s when-thanks largely to Antoine Faivre's work-it became an established object of academic research. ${ }^{3}$ Today there is an extensive body of scholarship, annual conferences, several professorships and specialist journals for the study of esotericism. Three definitions of esotericism stand out, which I will take up chronologically. Faivre (1994, pp. 10-15) defines esotericism as a "form of thought" marked by four intrinsic (1-4) and two extrinsic (5-6) characteristics: (1) correspondences (connections between "corresponding" parts of different "planes" of reality such as the correspondences between the seven planet powers and different minerals, plants, animals or parts of the human body), (2) living nature (nature understood as a spiritual and organic whole), (3) imagination and mediations (the spontaneous, partly intellectual, partly intuitive ability to sense the correspondences), (4) experience of transmutation (the process by which the human being can become a radically different, more evolved being), (5) the praxis of the concordance (the idea of an ancient profound wisdom, which is scattered in more or less imperfect pieces in actual historical philosophies and religions), and (6) transmission (the

3 The most influential scholar of esotericism before Faivre was probably Frances Yates (cf. Yates, 2001, 2002a, and 2002b). 
process of "initiation" to esoteric knowledge, which is transmitted continuously from master to pupil).

According to Kocku von Stuckrad, Faivre's definition is problematic, because, in contrast to what Faivre himself claims, it is an ideal type theory; not so much a description of the essential characteristics of actual esoteric currents, but "rather an instrument for clarifying what should, according to this definition, be understood by esotericism" (von Stuckrad, 2005 , p. 5). Von Stuckrad (2005, p. 10) argues that the term "esotericism" itself induces this kind of mistake, and, therefore, he usually prefers to talk about "the esoteric" in the old Greek sense of the "inner" and "secret". In von Stuckrad's view, "the pivotal point of all esoteric traditions are claims to 'real' or absolute knowledge and the means of making this knowledge available" (von Stuckrad, 2005, p. 10). The latest influential definition of esotericism comes from Wouter Hanegraaff who understands esotericism as a "waste basket" category of modern science and rationality; it contains everything that does not fit in the narrative of modern rationality. According to Hanegraaff, esotericism is the "dark canvas of presumed backwardness, ignorance or irrationality that modernity needs in order to paint the outlines of its own identity in shining colors of light and truth" (Hanegraaff, 2013, p. 254).

Given that there is a largely shared preconception of what counts as esoteric (for example, alchemy, Hermeticism and Kabbalah), for my purpose, the suggested definitions are not mutually exclusive but rather complementary. Schelling's esoteric influences (Jakob Boehme's theosophy in particular) in the Freedom Essay are quite well documented in classical studies. The most influential works in this respect are Walter Schulz's (1975) Die Vollendung des Deutschen Idealismus in der Spätphilosophie Schellings, Horst Fuhrmans's (1954) Schellings Philosophie der Weltalter, Ernst Benz's (2009) The Mystical Sources of German Romantic Philosophy, and Robert Brown's (1977) The Later Philosophy of Schelling - The Influence of Boehme on the Works of 1809-1815. However, despite the constantly growing interest in Schelling's thought since the turn of the 1990s, there is little discussion of the esoteric aspects of Schelling's thought today. At best, some authors, such as Slavoj Žižek, recognize the essential role esotericism plays in Schelling's metaphysics, but in the same breath they attempt to formalize and secularize the actual substance of Schelling's pivotal ideas. When it comes to Schelling's esoteric elements, they cannot, according to Žižek, "from our contemporary perspective [...] but appear as blatantly 'not true"” (Žižek, 2007, p. 7).

Sean McGrath's The Dark Ground of Spirit - Schelling and the Unconscious is a notable exception in this respect. McGrath underlines Schelling's esoteric influences, especially his acquaintance with Boehme's theosophy through the mediation of his contemporary Franz Baader. McGrath argues that it was precisely Schelling's turn to esotericism, which enabled him to develop the revolutionary idea of God's ground. All the three definitions of esotericism presented above are relevant for Schelling's metaphysics from different angles. When it comes to Faivre's definition, McGrath argues that "Faivre's four themes can be reduced to one: living nature" (McGrath, 2012, p. 22). Reduction might be a bit too strong an expression, but certainly the foundation of esoteric thought is nature understood as a constitutively meaningful and active organism. Without this idea it would be impossible to have the other constituents of Faivre's definition. Schelling's metaphysics of the will is obviously tied to the conception of living nature. For Schelling, there is no inert matter 
but only different "potencies" of the will ranging from completely blind drive to selfconsciousness.

When it comes to von Stuckrad's definition of the esoteric as "higher knowledge" hidden from the masses, Schelling is clearly also an esotericist in this sense. Already in his earlier "identity philosophy" Schelling presupposes that only relatively few people with a specific "organ" for proper philosophizing are able to intuit the most important truths; in the absence of this organ, the demonstration of philosophical truths is like telling to a blind person what it is like to see (Breazeale, 2014, pp. 100-101). Faivre's understanding of esotericism as a "form of thought" is also essential here. Esotericism is not a specific philosophy, but it is rather a mode of thought of its own which has affinities to philosophy but also to scientific, religious and artistic modes of thought. Therefore, esotericism departs from the "democratic" commitment of philosophy. In philosophy, at least understood in the narrow academic sense, the arguments are equally open to all people with ordinary intelligence. Esotericism, by contrast, resembles art in its subjectivity but is nevertheless associated with truth claims.

Finally, when it comes to Hanegraaff's definition of esotericism as the rejected other of modern rationality, Schelling's reputation speaks for itself. As already discussed, the new appraisal of Schelling has come with the price of actively forgetting of Schelling's roots. The conception of living nature is at the core of Schelling's metaphysics, but such a conception of nature is sharply at odds with the modern hegemony of a "disenchanted" age. Schelling's metaphysics is used for contemporary purposes, but at the same time its very foundation is cast into the supposed "anthropomorphic" past.

\section{The meaning of life}

In his work Does Life Have a Meaning? Milton Munitz subjects the title question to serious scrutiny. Munitz's twofold answer to the question of the meaning of life is based on his distinction between the observable universe, which is "the domain of interactive existents (including human existents) open to progressive inquiry," and Boundless Existence, which consists essentially in the very "fact that the universe Exists", and which "blocks all attempts to explain how or why the universe Exists" (Munitz, 1993, p. 113). According to Munitz, "viewed under the aspect of Boundless Existence, the lives of human existents are both unintelligible and lacking in any support or place in any overall designful scheme or intelligible order" (Munitz, 1993, p. 114). That is, in Munitz's view, life does not have a meaning in the cosmic sense. On the other hand, the observable universe is always observed through the lens of human subjectivity, and there is no human subjectivity without meanings in the plural. Consequently, for Munitz, life is never literally without meaning.

However, it is precisely the cosmic meaning of life which is generally at issue when people ask the meaning of life. In asking the meaning of life, the issue is not literally if there are meanings in life. Obviously, there are; addressing any questions is already activity based on meanings, and, consequently there are meanings in life in this minimal sense. The question of the meaning of life is, rather, if there is any systematic correspondence between human needs, hopes, and experiences in general, and the world itself.

In his work The Death of God and the Meaning of Life Julian Young understands the question of the meaning of life roughly this way. The historically oriented work is divided 
in two parts: before and after Nietzsche's famous declaration of "the death of God". Before the death of God, according to Young, the meaning of life was understood as a "true world" or "destination" to which this immanent life is a journey (Young, 2014, x). Nietzsche's declaration of the death of God marks a decisive turning point for Young. According to Young, "there is no version of the true-world answer to the question of the meaning of life that merits belief" (Young, 2014, xii). Young argues that "when Nietzsche reported, in 1882, that 'God is dead', he articulated no more than the truth [...] that Western culture has ceased to be, either overtly or covertly, a religious culture" (Young, 2014, xii). After Nietzsche, the question became rather whether, if even a subjective meaning of life is a plausible idea. However, Young finally argues that cosmic meaning of life is still a coherent idea. He claims to have found in late Heidegger "a form of pantheism", "a God which reveals itself as the world" (Young, 2014, p. 236). It is "a God who, unlike the God of traditional Christian theology, is genuinely mysterious and so genuinely 'far away', but one who is also, again unlike the Christian God, 'the nearest of all', immanent in the world, 'so close' to us" (Young, 2014, p. 235).

Young's interpretation of Heidegger could be contested, but his description of the meaning of life applies perfectly to Schelling. For Schelling, "will is primordial Being" (Schelling, 1809, p. 24). However, it is impossible to think of will without meaning. Schelling's esoteric conception of living nature enables him to conceive life as meaningful in the cosmic sense without the classical idea of God as an omnipotent being who is responsible for the meaning of life. While in traditional Christianity nature is conceived as raw material for God's will, for Schelling, nature itself is constitutively meaningful and willing. In particular, Schelling's conception of God's ground allows him to avoid a "true world" or "destination" conception of the meaning of life-both of which have been criticized with good reason by thinkers such as Nietzsche and Heidegger.

Such a conception is of course still defended at least by many Christian authors, but it has dubious characteristics both from theoretical and practical perspectives. True world and destination conceptions of the meaning of life presuppose that life in its immanence and multiplicity is reduced to transcendent oneness or subordinated to a telos which is either transcendent or placed in future. This applies not only to mainstream monotheistic religious traditions but also to Plato's idea world, varieties of Neoplatonism up to Spinoza, and to Hegel's and Marx's teleological systems. Theoretically, such views of the meaning of life do not take historicity and contingency seriously enough; they reduce everything to one grand narrative. Practically, true world and destination conceptions represent a mentality Nietzsche called life-denying; that which is beyond immanent life is valued higher than that which is here and now.

Schelling, by contrast, presents an account of the cosmic meaning of life, which is not based on ideas of a true world or destination. For Schelling, meaning is the most fundamental element of reality, which is also to say that, for him, life has a meaning in the cosmic sense. However, owing to his esoteric notion of God's ground, Schelling (1809, p. 33) conceives God as constant becoming instead of a transcendent origin of meaning. Contrary to the idea of a "true world", human reality here and now is, for Schelling, as real as it gets. In Schelling's metaphysics, the cosmic meaning of life is not dependent on any telos beyond humanity itself either. According to him, the human being "stands at the dividing line; 
whatever he chooses will be his act, but he cannot remain in indecision because God must necessarily reveal himself" (Schelling, 1809, p. 50). This way Schelling at the same time provides an account of the cosmic meaning of life and avoids the problems inherent in true world and destination conceptions of the meaning of life.

\section{References}

Benz, E. (2009/1968). The mystical sources of German romantic philosophy. (B. R. Reynolds \& E. M. Paul, Trans.). Eugene: Pickwick Publications.

Bowie, A. (2006/1993). Schelling and modern European philosophy. London \& New York: Routledge.

Breazeale, D. (2014). Exhibiting the particular in the universal: Philosophical construction and intuition in Schelling's Philosophy of Identity (1801-1804). In L. Ostaric (Ed.), Interpreting Schelling: Critical essays (pp. 91-119). Cambridge: Cambridge University Press.

Brown, R. (1977). The later philosophy of Schelling: The influence of Boehme on the works of 18091815. London \& New Jersey: Bucknell University Press.

Faivre, A. (1994). Access to Western Esotericism. Albany: State University of New York Press.

Fuhrmans, H. (1954). Schellings Philosophie der Weltalter: Schellings Philosophie in den Jahren 18061821 - Zum des Schellingschen Theismus. Düsseldorf: Verlag L. Schwann.

Hanegraaff, W. (2013). Esotericism and the Academy - Rejected knowledge in western culture. Cambridge: Cambridge University Press.

Heidegger, M. (1985). Schelling's treatise on the essence of human freedom. Athens: Ohio University Press.

McGrath, S. J. (2012). The dark ground of spirit - Schelling and the unconscious. Cornwall: Routledge.

Munitz, M. (1993). Does life have a meaning? New York: Prometheus Books.

Norman, J., \& Welchman, A. (Eds). (2004). The New Schelling. Wiltshire: Continuum.

Schelling, F. (1992/1809). Philosophical inquiries into the nature of human freedom. (J. Gutman, Trans.). La salle: Open Court.

Schulz, W. (1975/1955). Die Vollendung des Deutschen Idealismus in der Spätphilosophie Schellings. Pfullingen: Neske.

Snow, D. (1996). Schelling and the end of idealism. Albany: State University of New York Press.

Von Stuckrad, K. (2005). Western esotericism - A brief history of secret knowledge. London \& Oakville: Equinox Publishing.

Wirth, J. (Ed). (2005). Schelling now - Contemporary readings. Bloomington \& Indianapolis: Indiana University Press.

Yates, F. (2002a/1964). Giordano Bruno and the hermetic tradition. London \& New York: Routledge.

Yates, F. (2002b/1972). The Rosicrucian Enlightenment. London \& New York: Routledge.

Yates, F. (2001/1979). The occult philosophy in the Elizabethan Age. London \& New York: Routledge.

Young, J. (2014). The death of god and the meaning of life. New York: Routledge.

Žižek, S. (2007). The indivisible remainder - On Schelling and related matters. London \& New York: Verso.

Department of Philosophy and Social Sciences, University of Jyväskylä

PO Box 35,

FI-40014 University of Jyväskylä

Keskussairaalantie 2,

Building Opinkivi (OPK), Finland

Email: olli.p.pitkanen@student.jyu.com 
Reproduced with permission of copyright owner.

Further reproduction prohibited without permission. 